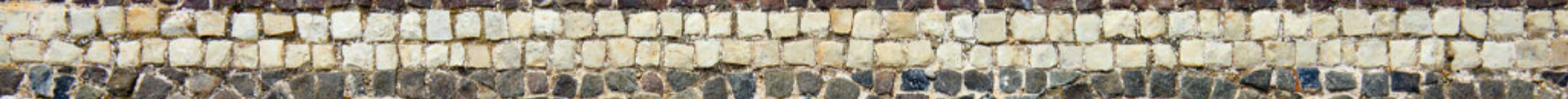

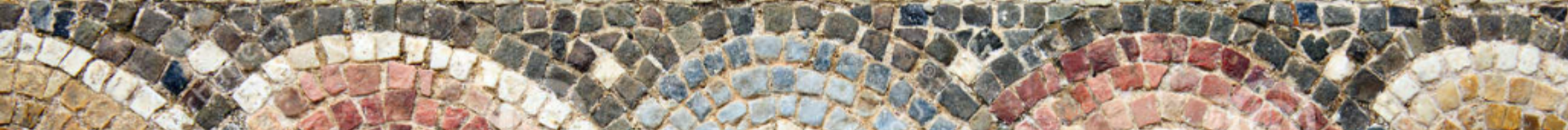
15.

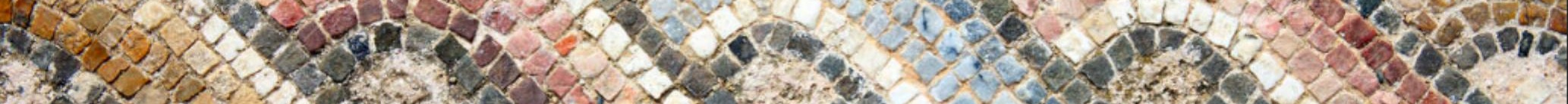

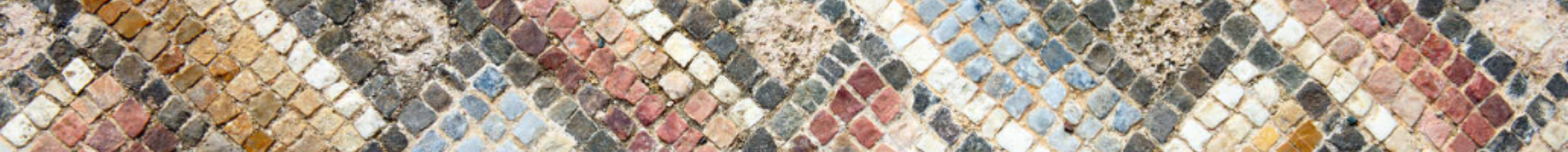

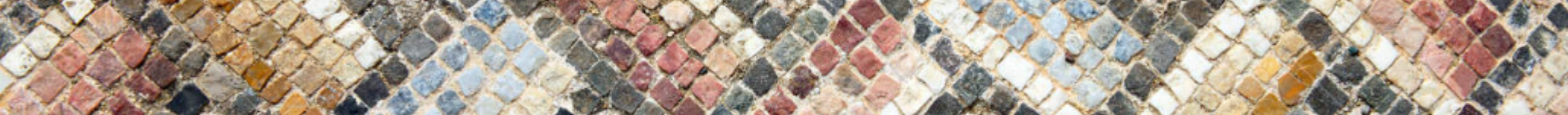

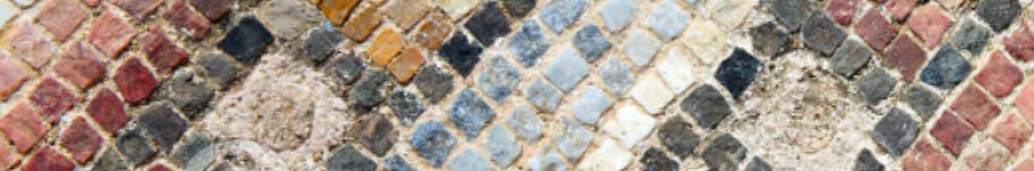

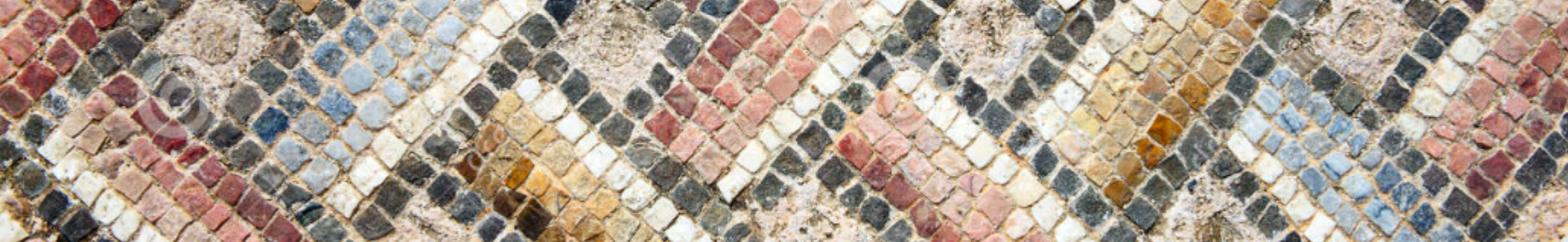

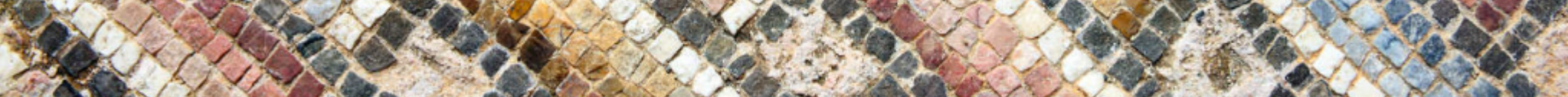

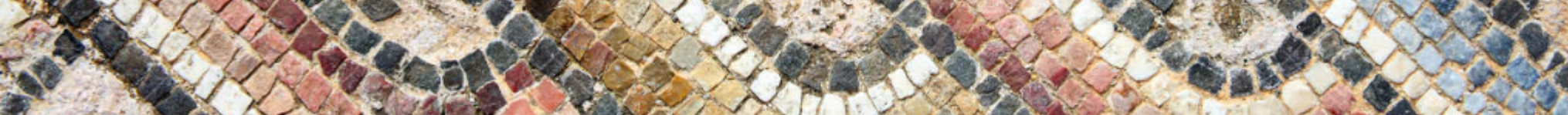

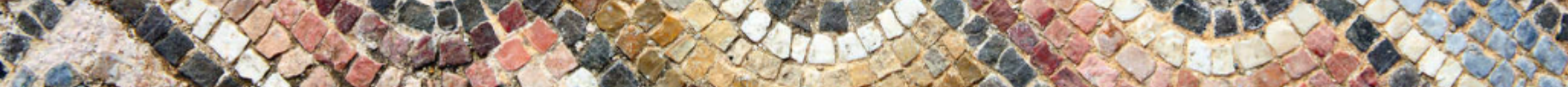

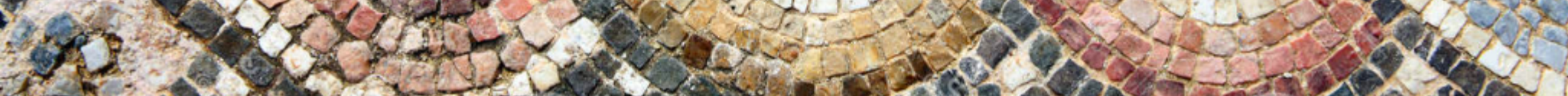

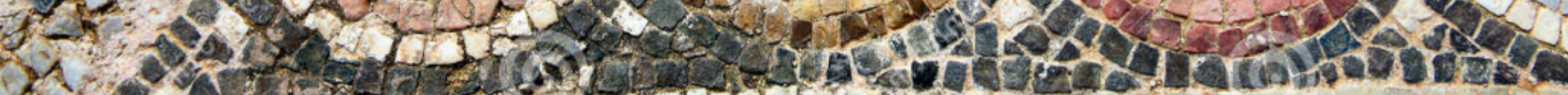
31. 3 -

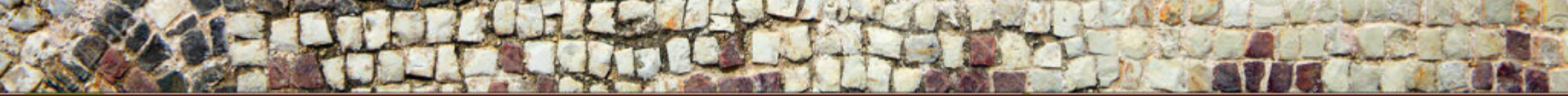

2019.2 . Ano xxxVI . Número 38

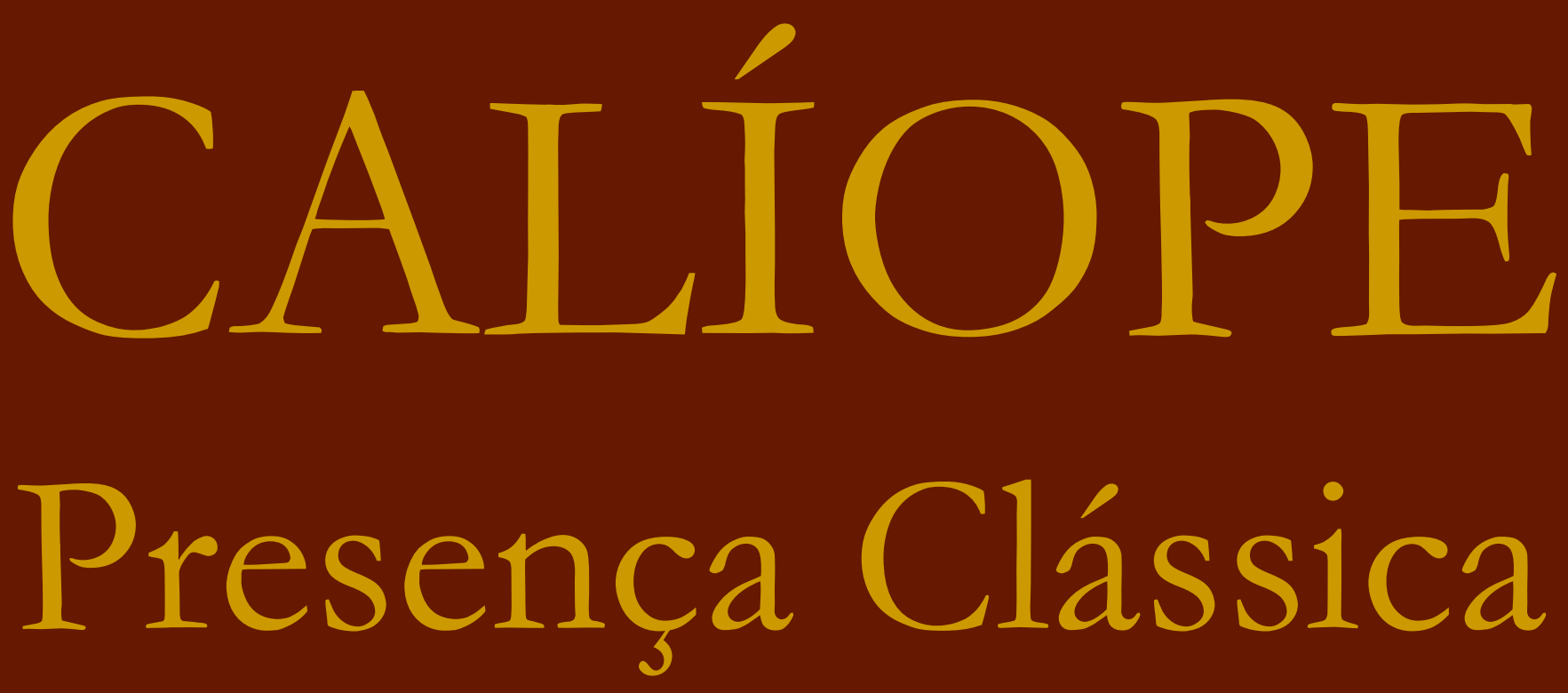

separata 1 
2019.2 . Ano XXXVI . Número 38

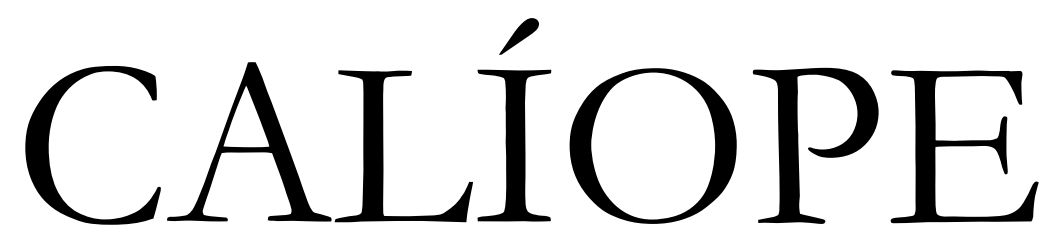

Presença Clássica ISSN 2447-875X

separata 1

Programa de Pós-Graduação em Letras Clássicas

Departamento de Letras Clássicas da UFRJ 
Universidade Federal do Rio de Janeiro REITORA Denise Pires de Carvalho

Centro de Letras e Artes

DECANA Cristina Grafanassi Tranjan

Faculdade de Letras

DIRETORA Sonia Cristina Reis

Programa de Pós-Graduação em Letras Clássicas

COORDENADOR Ricardo de Souza Nogueira

VICE-COORDENADORA Arlete José Mota

Departamento de Letras Clássicas

CHEFE Fábio Frohwein de Salles Moniz

SUBCHEFE Eduardo Murtinho Braga Boechat

Organizadores

Fábio Frohwein de Salles Moniz

Rainer Guggenberger

Conselho Editoria

Alice da Silva Cunha

Ana Thereza Basilio Vieira

Anderson de Araujo Martins Esteves

Arlete José Mota Auto Lyra Teixeira

Ricardo de Souza Nogueira Tania Martins Santos

Conselho Consultivo

Alfred Dunshirn (Universität Wien)

David Konstan (New York University)

Edith Hall (King's College London)

Frederico Lourenço (Universidade de Coimbra)

Gabriele Cornelli (UnB)

Gian Biagio Conte (Scuola Normale Superiore di Pisa)

Isabella Tardin (Unicamp)

Jacyntho Lins Brandão (UFMG)

Jean-Michel Carrié (EHESS)

Maria de Fátima Sousa e Silva (Universidade de Coimbra)

Martin Dinter (King's College London)

Victor Hugo Méndez Aguirre (Universidad Nacional Autónoma de México)

Violaine Sebillote-Cuchet (Université Paris 1)

Zélia de Almeida Cardoso (USP)

Capa

Fábio Frohwein de Salles Moniz

Editoração

Fábio Frohwein de Salles Moniz

Revisão de texto

Fábio Frohwein de Salles Moniz

Revisão técnica

Fábio Frohwein de Salles Moniz

Programa de Pós-Graduação em Letras Clássicas | Faculdade de Letras - UFR

Av. Horácio Macedo, 2151 - sala F-327 - Ilha do Fundão 21941-917 - Rio de Janeiro - RJ www.letras.ufrj.br/pgclassicas - pgclassicas@letras.ufrj.br 


\section{Da língua dos clássicos aos clássicos na língua: uma leitura do poema "Vênus" de Carlos Drummond de Andrade 1 Mafalda Frade}

RESUMO

O presente artigo tem como objetivo analisar a forma como a linguagem e o mito clássico são utilizados no poema "Vênus" de Carlos Drummond de Andrade para explorar diversas facetas do amor. De facto, na obra de Drummond de Andrade, dois dos eixos semânticos utilizados são o do amor e o da Cultura Clássica, que são apresentados de diversas formas. Nessa composição poética, os dois unem-se e, através do uso das línguas clássicas na criação de neologismos, elabora-se um jogo de palavras que permite ao sujeito poético revelar o que pensa e sente a propósito das diversas faces do amor.

PALAVRAS-CHAVE

Drummond de Andrade; Vénus; poesia lírica; amor.

SUBMISSÃO 31.12.2019 | APROVAÇÃO 04.01.2020 | PUBLICAÇÃO 20.03.2020

DOI https://doi.org/10.17074/cpc.v2i38.31353 
Da língua dos clássicos aos clássicos na língua [...] | Mafalda Frade

INTRODUÇÃO

arlos Drummond de Andrade é um poeta multifacetado, em cuja obra

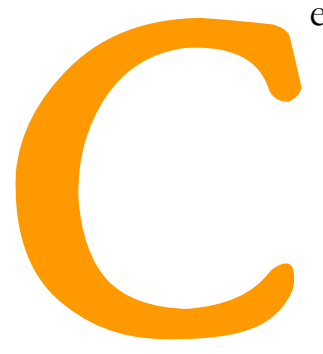

encontramos poemas de diversas temáticas, tais como a observação do quotidiano, a preocupação com o homem enquanto ser humano e ser-no-mundo, realçando-se o olhar sobre questões sociais e políticas, a reflexão sobre a poesia e a linguagem e ainda o amor. ${ }^{2}$

É patente, assim, que, entre outros temas, a poesia de Drummond de Andrade surge, variadas vezes, eivada de sentimentos amorosos ${ }^{3}$ que podem assumir inúmeras formas. De facto, o amor é não apenas olhado como emoção que denota afeto e paixão, mas também como sentimento de afeição fraternal para com alguém que não é objeto de desejo. ${ }^{4}$

Nesse âmbito, o amor evocado tanto pode ser platónico como mostrar uma face profundamente erótica que se revela absolutamente natural. De facto, o sujeito lírico constrói, em variados poemas, uma "explosiva e sublime conversão de amor e sexo, de almas e corpos, sentimentos e suores em Amor maiúsculo, enigmaticamente terreno e transcendente, concreto e místico".

Segundo Maria de Santa-Cruz, "a 'boa' poesia, como toda a espécie de amor, tem sempre uma componente erótica", bem patente em Drummond de Andrade, para quem o Amor de apresenta

como uma das vias naturais do conhecimento e da própria experiência terrena do divino [...] e da eternidade; e a Mulher que se dá (em oposição às "mulheres gulosas" e recalcadas ou às prostitutas reformadas), |é| uma das maiores forças da Natureza, o retiro onde o homem, enfim, encontra a paz, a metade indispensável e gozosa do Uno. ${ }^{7}$ 
Esses dois eixos da poesia amorosa - o platónico e o erótico - estão bem patentes num campo que perpassa diversas vezes pelas suas obras: o da Cultura Clássica.

De facto, há variadíssimas referências à Antiguidade Clássica na poesia de Carlos Drummond de Andrade, e também aqui o poeta revela uma face multifacetada, na medida em que, ao longo da sua poesia, não se limita ao uso de personagens mitológicas - como as evocadas, por exemplo, na composição poética "Balada do amor através das idades", "O poeta escolhe o seu túmulo", "Relógio do Rosário", "Canto órfico", "11 "Isso é aquilo"12 -, mas também refere autores greco-latinos como Platão, Ovídio, Virgílio, Horácio ou Aristóteles - vejam-se os poemas "Amor - pois que é palavra essencial", ${ }^{13}$ "Quando desejos outros é que falam"14 e "A língua francesa", "Canção para ninar você", ${ }^{16}$ "A bruxa" ou "Isso é aquilo". ${ }^{18}$ Para além disso, refere ainda realidades inusitadas, como a métrica da poesia clássica - caso dos poemas "Estâncias", "Arte poética"20 ou "A paixão medida"21 ou caraterísticas gramaticais - como acontece em composições em que rememora, por exemplo, as declinações, como é o caso de "Rosa rosae". 22

A língua dos clássicos também surge bem marcada, pela citação de pequenos trechos e palavras ou expressões latinas em algumas das suas composições - como sucede nos poemas "Noite na repartição", 23 "O banco que serve a meu pai" ${ }^{24}$ ou "Em louvor da miniblusa". 25

\section{O POEMA "VÊNUS"}

Interessa-nos, contudo, a este nível, um poema específico "Vênus" - em que à personagem mitológica de Vénus - Afrodite, na versão grega - se junta todo um jogo linguístico baseado em neologismos que permite ao sujeito poético rememorar inúmeros mitos clássicos e, ao mesmo tempo, transportar para o presente o mito da deusa do amor, reinventando-o e dando-lhe profundidade, na medida em que Vénus é associada não apenas ao amor sexual, mas também a outros tipos de amor. 
A figura de Vénus encaixa perfeitamente na temática amorosa de Drummond de Andrade. A antiga divindade latina ${ }^{26}$ foi, desde muito cedo, assimilada à deusa grega Afrodite, cujo riquíssimo mito envolve inúmeros episódios em que o amor ocupa um lugar central. De facto, "Afrodite é considerada a deusa do amor e do apelo carnal tanto dos homens como dos bichos, bem como encantadora de toda a fauna, metonímia de natureza, e por extensão, de cosmos". ${ }^{27}$

Na obra de Drummond de Andrade, é o nome Vénus que é utilizado, por norma, para evocar a deusa do amor, e o poeta itabirano referencia-a inúmeras vezes na sua obra, utilizando-a para expressar ideias variadas. No poema "No pequeno museu sentimental", ${ }^{28}$ por exemplo, essa personagem evoca, pela expressão usada - "montes de Vênus" -, o amor sexual, bem percetível na segunda estrofe, em que o sujeito lírico se atribui o epíteto metafórico de "pastor felante".

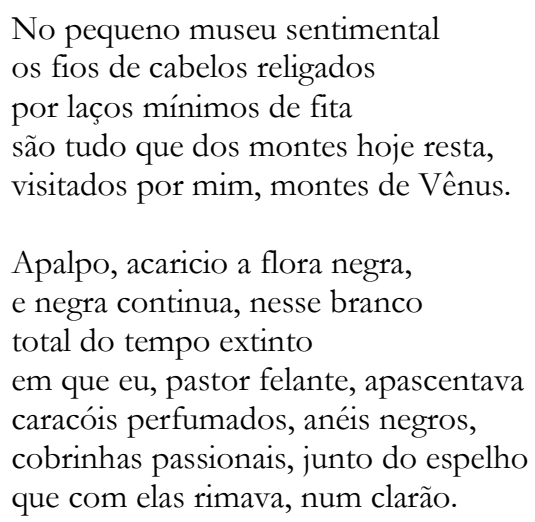

O mesmo sucede na composição "Adeus, camisa de Xanto", ${ }^{29}$ em que a expressão "camisa de Vênus" é diretamente relacionada com o ato sexual:

Adeus, camisa de Xanto!

Adeus, camisa de Vênus!

O sêmen fugiu. Nem pranto

nem riso. Estamos serenos. 
Calíope: Presença Clássica | 2019.2 . Ano xxxvi . Número 38 (separata 1)

Baixou a noite seu manto

sobre a cansada virilha.

(Sexo e noite formam ilha.)

Adeus, camisa de Vênus,

adeus, camisa de Xanto!

Já gozamos. Já morremos.

Já na composição "A loja feminina", Vénus surge como a divindade capaz de humanizar até estátuas, dotando-as de atributos femininos aliciantes que despertam o desejo erótico:

Cinco estátuas recamadas de verde

na loja, pela manhã, aguardam o acontecimento.

É próprio de estátuas aguardar sem prazo e cansaço que os fados se cumpram ou deixem de cumprir-se.

Nenhuma ruga no imobilismo

de figurinos talhados para o eterno,

que é, afinal, novelo de circunstâncias.

Iguais as cinco, em postura vertical, um pé à frente do outro quase suspenso

na hipótese de voo, que não se consumará, em direção da porta sonora

a ser aberta para alguém desconhecido

- Vênus certamente, face múltipla -

assomar em tom de pesquisa,

apontando o estofo, o brinco, o imponderável

que as estátuas ocultam em sigilo de espelhos.

$[\cdots]$

Sabem que Vênus, cedo ou tarde, provavelmente tarde e sem pintura, chegará.

Chega, e o simples vulto aciona as esculturas.

Ao cintilar de vitrinas e escaninhos, objetos deixam de ser inanimados. Antes de chegar à pele rósea, a pulseira cinge no ar o braço imaginário. 
Da língua dos clássicos aos clássicos na língua [...] | Mafalda Frade

\author{
O enfeite ocioso ganha majestade \\ própria de divinos atributos. \\ Tudo que a nudez torna mais bela \\ acende faíscas no desejo. \\ As estátuas sabem disto e propiciam \\ a cada centímetro de carne \\ uma satisfação de luxo erótico.
}

Esse poder de atração assume o seu expoente máximo no poema "Vênus". De facto, nessa composição o mito é aproveitado ao máximo e assume não apenas essa vertente erótica, mas uma face multifacetada, tão característica do poeta itabirano.

De facto, nesse poema, Vénus surge como metáfora do amor nas diversas formas que esse consegue assumir. É, assim, um poema onde o sujeito poético explora variadas e diferentes faces do amor, indo muito além do erotismo que o mito afrodisíaco, por norma, evoca.

Eis o poema:

\author{
Vênus de calça comprida é \\ Vênus calcianadiomênica \\ Vênus calcispúmica \\ Vênus calcitrite \\ Vênus de calça comprida \\ é Vênus calcirízica \\ Vênus calcigênitrix \\ Vênus calcimílica \\ De calça comprida Vênus é Vênus \\ Calcicranachiana \\ Calciarlesiana \\ Calcicapitulina \\ Calcibelvedérica \\ é Vênus de calça comprida \\ calcieleusiana \\ calcitriptolêmica \\ Vênus calcipersefônica \\ Vênus calciproserpínica
}


Calíope: Presença Clássica | 2019.2 . Ano xxxvi . Número 38 (separata 1)

\author{
De calça comprida \\ Vênus calcicarôntica \\ Calcifarnésica Vênus \\ Vênus calcilaomedôntica \\ Vênus calcionfálica \\ Vênus é de calça comprida \\ Calcimegárica \\ Vênus calciedípica \\ Vênus calciateneica \\ - de calça comprida - calcidedálica \\ Vênus calcimeleágrica \\ Vênus calciargonáutica \\ Vênus calcibelerofôntica \\ de calça comprida Vênus \\ Vênus calcidanáidica \\ Vênus calcihemofroidítica \\ Vênus calcicomprida \\ e sempre, nua, Vênus.
}

Salta à vista, em primeiro lugar, que o poema gira todo em torno da criação de inúmeros epítetos, trazendo à memória, segundo Barbas, a composição poética de Jorge de Sena "Quatro sonetos a Afrodite Anadiómena", em que o poeta brinca também com os epítetos da deusa do amor, recriando igualmente a língua de forma a permitir o "jogo com as sonoridades da linguagem que exibem sentidos além dos directamente significados", 30 como observamos, por exemplo, no seguinte trecho: ${ }^{31}$

Timbórica, morfia, ó persefessa, meláina, andrófona, repitimbídia, ó basilissa, ó scótia, masturlídia, amata cíprea, calipígea, tressa

de jardinatas nigras, pasifessa, luni-rosácea lambidando erídia, erínea, erítia, erótia, erânia, egídia, eurínoma, ambológera, donlessa. 


\section{Da língua dos clássicos aos clássicos na língua [...] | Mafalda Frade}

Nesse poema de Jorge de Sena, é “a própria matéria linguística, ao nível da linearidade fónica e grafemática do significante, que sofre um processo de transformação", ${ }^{32}$ e o mesmo acontece em "Vênus", em que Drummond de Andrade, tal como acontece nos poemas de Sena, elabora um texto poético criando neologismos a partir de contributos lexicais de diferentes idiomas. $^{33}$

No caso da composição do poeta itabirano, os epítetos criados relacionam-se, na sua totalidade, com uma característica primordial atribuída a Vénus: o vestir de calças compridas.

A calça comprida, em nosso entender, transporta-nos para o presente - a deusa, como é óbvio, nunca é representada de calças, já que, na Cultura Clássica, essa peça de roupa não era usada. Mas hoje, muitas mulheres usam calças - e aqui parece que, por sinédoque, Vénus surge, para o sujeito poético, e na atualidade, como o ideal feminino, a representação da mulher, de ontem como de hoje, que atrai o homem.

Partindo dessa ideia, interessa explorar os diversos epítetos, que mais não são do que neologismos criados a partir do nome 'calça' a que se juntam nomes ou adjetivos sobretudo de caráter mitológico, formando um novo adjetivo. Tendo isso em consideração, o que pretende transmitir o sujeito poético com esse panegírico à deusa? E, por extensão, à mulher?

De notar, em primeiro lugar, que surgem na composição poética três epítetos que demonstram as origens de Vénus e também a sua capacidade de ser força geradora de vida: "calcianadiomênica", "cacispúmica" e "calcitrite".

Esses epítetos remetem para um mito de origem. De facto, o adjetivo "Anadiómena" (relacionado com o verbo grego

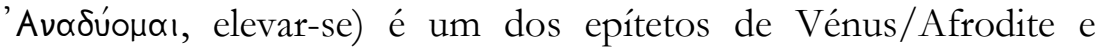
remete para o seu nascimento das águas, tema que prevalece até aos dias de hoje na pintura, escultura ou literatura.

Essa referência é reforçada pelo epíteto seguinte, 'calcispúmica', formado a partir dos nomes "calça" e "espuma". Esse último remete diretamente para a espuma do mar em que, segundo o mito, Vénus foi gerada. De notar que o próprio nome 
"Afrodite" evoca esse acontecimento, já que ợpós significa precisamente "espuma".

Já o terceiro epíteto dessa quadra não remete para as origens de Vénus, mas sim para aquilo a que ela dá origem. Tritê, em grego, significa "terceiro" (como sucede em latim) e, nesse caso, parece-me que o epíteto remete para a nota musical trite synemmenon (na atualidade, si bemol) cuja origem, na doutrina pitagórica da harmonia das esferas celestes, ${ }^{34}$ foi associada a Vénus. ${ }^{35}$

Assim se mostra a origem de Vénus e se percebe que ela própria é fonte de vida, ideia que se mantém na segunda estrofe, em que se evoca, pela primeira vez, o amor parental, num neologismo em que, ao vocábulo "calças", se une uma palavra provinda diretamente do latim: Vénus é genitrix, mãe geradora de vida.

\author{
Vênus de calça comprida \\ é Vênus calcirízica \\ Vênus calcigênitrix \\ Vênus calcimílica \\ De calça comprida Vênus é Vênus \\ Calcicranachiana \\ Calciarlesiana \\ Calcicapitulina
}

Nesse ponto, tem início um outro eixo do poema, em que se demonstra que a deusa é ela própria gerada, uma e outra vez, pela mão de artistas que espalharam o seu culto por todo o Império romano.

Surgem assim no poema variadas alusões a imagens esculturas e pinturas - de Vénus, cujos epítetos criados pelo sujeito poético não o são apenas a partir de palavras das línguas clássicas, mas também de outras que o não são: Vénus é apresentada como 'calcirízica', neologismo formado a partir do verbo grego oupi $\zeta \omega$ (proceder como um sírio), remetendo-nos para a imagem da Dea Siria, ou Atargatis, com quem Vénus foi frequentemente 
associada. ${ }^{36}$ Para além disso, a deusa é caracterizada como "calcimílica", em alusão à Vénus de Milo. ${ }^{37}$

A estrofe seguinte segue o mesmo padrão: ela é Vénus calcicranachiana, numa referência à imagem de Vénus pintada por Lucas Cranach ${ }^{38}$ é calciarlesiana, relembrando-se assim a escultura da Vénus de Arles $;^{39}$ e calcicapitulina, numa alusão (com corruptela do nome latino) a Vénus Capitolina. ${ }^{40}$

Note-se que, nas obras de arte aludidas, a nudez está sempre presente (o que é relevante para o fim do poema, como veremos), símbolo não apenas das origens dos seres (todos nascemos nus), mas também da naturalidade que o amor pode assumir, na sua versão sexual, ainda que haja espaço para a pudicícia, dado que, em algumas das imagens aludidas, a deusa surge a tapar o corpo.

Mais tarde, no início da quarta e sexta estrofes, o sujeito poético retoma essa rememoração, afirmando que Vénus é ainda calcibelvedérica, numa clara menção à escultura de Vénus de Belvedere, ${ }^{41}$ e calcifarnésica, trazendo para o poema a imagem de Vénus Calipígia, da Coleção Farnese. ${ }^{42}$ Em meu entender, é a forma encontrada para não deixar o leitor esquecer esse lado nu, cru, físico do amor, que começa a ser apresentado, após as duas primeiras estrofes, de outra forma.

De facto, após a alusão às origens e proliferação das imagens de Vénus e da nudez que lhe é tão associada, o sujeito poético dedica-se a construir uma série de novos epítetos, recorrendo de novo à utilização do vocábulo "calças", a que agora vai associar sobretudo nomes de personagens mitológicas, cuja escolha, ainda que aparentemente aleatória, revela um trabalho criterioso.

De facto, há epítetos que remetem para o amor entre pais e filhos. É o que sucede na quarta estrofe, em que os epítetos "calcieleusiana" e "calcitriptolêmica" nos transportam para o amor paternal de Elêusis. Filho de Hermes, numa das versões do mito, e figura epónima da cidade de Elêusis, esse herói teve um filho denominado Triptólemo. Um dia, Deméter, ao tentar tornar 
Triptólemo imortal, mergulhou-o no fogo, e isso suscitou a ira de Elêusis, que gritou, acabando por ser morto pela deusa. ${ }^{43}$

Elêusis é também, por excelência, o local de culto de Deméter, cujo amor maternal é relembrado na quinta estrofe, nos epítetos "calcipersefônica", "calciproserpínica" e "calcicarôntica", que remetem para o rapto de Perséfone/Prosérpina (filha de Deméter) e consequente descida aos Infernos (onde se encontra Caronte), que despoletam o desgosto materno.

Vénus é, assim, conotada não apenas com o amor sexual, mas também como a deusa que preside ao amor parental e filial, que volta a ser mencionado na sétima estrofe, nos epítetos "calciedípica" e "calcidedálica" e na nona estrofe, através do epíteto "calcidanáidica".

De facto, o epíteto "calciedípica" remete para o mito do amor incestuoso de Édipo, que culmina com o suicídio materno e o exílio do herói. ${ }^{44}$ Já "calcidedálica" traz à memória a figura de Dédalo, símbolo do inventor e do artista universal, que procura salvar-se e salvar o filho do labirinto em que ambos tinham sido encarcerados através da invenção das asas. Não consegue, porém, todos os seus intentos, já que, como Deméter ou Elêusis, o seu amor sofre um enorme revés (nesse caso, Ícaro morre). ${ }^{45}$

Por fim, o amor paternal (ou a falta dele) e o maternal também estão presentes no epíteto "calcidanáidica", que alude a Dánae, antepassada de Héracles. Filha do rei de Argos, Acrísio dá à luz Perseu, fruto da sua união com Zeus e é abandonada à sua sorte por seu pai, que temia morrer às mãos do neto (o que vem, de facto, a acontecer). Perseu, já adulto, mata a Medusa, decapitando-a, ${ }^{46}$ e do sangue que jorra nasce Pégaso, o cavalo alado, que acaba por ajudar Belerofonte a matar a Quimera. Esse mesmo cavalo é usado por Estenebeia, mulher do rei de Tirinte, para tentar fugir da vingança de Belerofonte. De facto, ela apaixonara-se por Belerofonte quando esse chegara a Tirinte, mas fora rejeitada e tentara vingar-se do herói, acusando-o de violação. Foi esse episódio que conduziu ao afastamento de Belerofonte de Tirinte e à luta contra a Quimera. ${ }^{47}$ 


\section{Da língua dos clássicos aos clássicos na língua [...] | Mafalda Frade}

Esse episódio de Belerofonte, marcado pelo amor adúltero e lascivo, remete-nos para o epíteto de Vénus mencionado na estrofe oitava, "calcibelerofôntica". Esse tipo de amor, contudo, já fora referido anteriormente, na sexta estrofe, através do epíteto "calcionfálica", com o qual se introduzem no poema variados epítetos que remetem para a história de Héracles, dando-se aqui relevo às suas aventuras e desventuras amorosas e à paixão a elas associada.

Nesse âmbito, o amor é, então, adúltero: ao denominar Vénus "calcionfálica", o sujeito poético evoca o mito de Ônfale, rainha da Lídia, que assume uma relação com Héracles, na altura casado com Dejanira. ${ }^{48}$ No entanto, no mito, há também lugar para o amor puro: Vénus é "calcimegárica" (sétima estrofe), numa alusão a Mégara, filha do rei de Tebas e primeira mulher de Héracles, cuja união com o herói termina de modo trágico, quando esse mata os filhos de ambos num acesso de loucura provocado por Hera ${ }^{49}$ (e de novo se retoma o tópos do amor parental).

O mesmo tipo de alusão ocorre perante o epíteto "calcimeleágrica" (oitava estrofe), em que se evoca o amor de Meleagro por Atalante. Nesse episódio, o herói, casado com Cleópatra, mas apaixonado por Atalante, depois de matar um monstruoso javali enviado por Ártemis, oferece os despojos à sua amada, enfurecendo os companheiros. Irritado com a reação, Meleagro mata os tios e é depois morto pela mãe. ${ }^{50}$ Voltamos então a estar perante vários tipos de amor: puro, adúltero, filial (em relação aos tios), parental.

Note-se que Meleagro, numa versão do mito de Jasão e o Velo de Oiro, faz parte do conjunto de argonautas, aqui recordados pelo epíteto "calciargonáutica", cuja nau atraca na ilha de Lemnos para que se unam às habitantes, todas mulheres, dando-lhes filhos, num processo que parece associado ao amor fugaz, lascivo e sexual. É esse grupo de heróis, em que se encontrava Héracles numa das versões do mito, explorada por Diodoro Sículo, ${ }^{51}$ que Laomendonte (rememorado no epíteto "calcilaomedôntica") procura matar, de modo a evitar o cumprimento de uma promessa feita a Héracles: a oferta dos seus 
cavalos divinos em troca da destruição de um monstro marinho enviado por Posídon para castigar os troianos. Nesse âmbito, a figura de Héracles é também convocada para evocar o amor fraternal (ou a falta dele) lato sensu, isto é, entre companheiros ou amigos. ${ }^{52}$

O mesmo tipo de amor fraternal parece ser evocado através do epíteto "calciateneica", na sétima estrofe, em que a figura de Atena é associada a Vénus. Nesse âmbito, considero que o sujeito poético não rememora aqui a deusa que influencia as artes e toda a atividade inteligente, mas sim a que protege aqueles de quem gosta, entre os quais Héracles, durante a Guerra de Troia (cujo início - o amor adúltero de Páris e Helena - é assim aqui evocado de forma quase subliminar)..$^{53}$

Um último epíteto, na última estrofe, parece resumir todo esse tópos do amor: o epíteto "calcihemofroidítica", reminiscência de Hermafrodito, filho de Hermes e Afrodite, ser uno e duplo, em simultâneo, que não assume apenas uma faceta, ${ }^{54}$ leva-nos a pensar que o amor é, ele próprio, um sentimento com diversas facetas, como se explora ao longo do poema.

\section{CONCLUSÃO}

Perante tudo isso, é possível concluirm que os neologismos criados remetem para diversas realidades associadas a Vénus, metáfora do Amor, convocando-se todas as faces dele. Nesse âmbito, a riqueza da mitologia da Antiguidade clássica, aliada ao jogo linguístico observado - em que, a uma base comum, se unem não apenas vocábulos em língua portuguesa, mas também em latim e não apenas formas adjetivas, mas nomes que passam a dar origem a adjetivos - em toda a composição poética, permite o desenvolvimento de uma imagética metafórica muito produtiva, dando origem a uma panóplia de sentidos, todos relacionados com o tópos do amor.

De facto, nesse poema, não é apenas o amor lascivo e sexual que se apresenta: há também amor filial, amor parental, 
amor puro, amor adúltero, amor efémero, amor duradouro, amor incestuoso, amor fraternal.

O sujeito lírico expõe, assim, as diversas facetas amorosas, para concluir, na última estrofe, que não é importante a face que o amor toma - daí o epíteto 'calcihemofroidítica' -, nem se estamos perante uma mulher amada da Antiguidade ("danáidica") ou da atualidade ("calcicomprida").

O que importa ao sujeito lírico, afinal, e depois da exposição cuidada dos diversos tipos de amor, é a Mulher na sua essência, no seu estado mais natural.

Retoma-se, assim, na última estrofe, ideias já exploradas na primeira: a Mulher é sempre Vénus, fonte de desejo, hoje, de calça comprida, como outrora, e é na sua nudez (com a qual nascemos, como se vê na primeira estrofe), metáfora da inocência original do Ser, que o poeta a busca, já que é essa nudez do amor que se quer "natural", como evoca uma das obras de Drummond de Andrade, ${ }^{55}$ que permite a união entre corpos e almas, trazendo paz, como ele próprio confessa:

Mulher andando nua pela casa envolve a gente de tamanha paz. ${ }^{56}$ 
Calíope: Presença Clássica | 2019.2. Ano xxxvi . Número 38 (separata 1)

\section{ABSTRACT}

This article aims to analyze how language and classical myths are used in the poem "Venus" by Carlos Drummond de Andrade to explore various facets of love. In fact, in Drummond de Andrade's work, the semantic axes of love and classical culture are presented in various ways. In this poetic composition, the two unite and, by using classical languages in the creation of neologisms, he elaborates a word game that allows him to reveal what he thinks and feels about the different faces of love.

KEYWORDS

Drummond de Andrade; Venus; Love poetry; Love. 


\section{Da língua dos clássicos aos clássicos na língua [...] | Mafalda Frade}

REFERÊNCIAS

ANDRAde , Carlos Drummond de. Nova reunião: 19 livros de poesia. Rio de Janeiro: José Olympio, 1985.

José. São Paulo: Companhia das letras, 2012b.

. A rosa do povo. São Paulo: Companhia das Letras, 2012a.

. O amor natural. São Paulo: Companhia das Letras, 2013.

. A paixão medida. São Paulo: Companhia das Letras, 2014.

APEL, Willi. Harmony of the Spheres, In: RANDEL, Don Michael. The Harvard Dictionary of Music. Cambridge: Harvard University Press, 2003. p. 382.

BARBAS, Helena. A procura da poesia: Carlos Drummond de Andrade. Olhares luso-brasileiros sobre literatura. Lisboa: Universidade Católica Portuguesa, 2002.

barbosa, Rita de Cássia. Poemas eróticos de Carlos Drummond de Andrade. São Paulo: Ática, 1987.

BLACKBURn, Bonnie J. The Lascivious Career of B-Flat. In: BLACKBURN, Bonnie J.; STRAS, Laurie. Eroticism in Early Modern Music. London; New York: Routledge, 2016. p. 19-42.

Bueno, Danilo Rodrigues. A função poético-crítica em Jorge de Sena: problemáticas do poeta moderno. São Paulo: Universidade de São Paulo, 2009.

CARlos, Luís Adriano. Fenomenologia do discurso poético. Porto: Campo das Letras, 1999.

CAstanheira, Carolina Parizzi. De institutione musica de Boécio - livro 1: tradução e comentários. 2009. 153 páginas. Dissertação de Mestrado em Letras (Estudos Literários). Belo Horizonte: Universidade Federal de Minas Gerais, 2009.

CURTIS, Gregory. Disarmed: The Story of the Venus de Milo. New York: Alfred A. Knopf, 2003.

GRIMAL, Pierre. Dicionário da mitologia grega e romana. Lisboa: Difel, 1992.

GRUMmOND, Nancy Thomson (ed.). Encyclopedia of the History of Classical Archaeology. London; New York: Routledge, 1996.

HASKELL, Francis; PENNY, Nicholas. Taste and the Antique: the Lure of Classical Sculpture, 1500-1900. [S.1.]: Yale University Press, 1981.

KLEINER, Fred S. Gallia Graeca, Gallia Romana and the Introduction of Classical Sculpture in Gaul. American Journal of Archaeology, v. 77.4, p. 379-390, 1973. 
KROPP, Andreas J.M. Jupiter, Venus and Mercury of Heliopolis (Baalbek). Syria, v. 87 , p. 229-264, 2010.

LIMA, Francesco Jordani Rodrigues. Amor: a palavra essencial da poesia erótica de Drummond. Diadorim, v. 1, p. 96-106, 2006.

NeSSELRATH, Arnold. The Venus Belvedere: an Episode in Restoration. Journal of the Warburg and Courtauld Institutes, v. 50, p. 205-214, 1987.

OLIVEIRA, Andreia. O amor é a memória/ que o tempo não mata: algumas definições de amor em Carlos Drummond de Andrade. Olho d'água, São José do Rio Preto, v. 6.1, p. 27-37, 2014.

PICKUP, Sadie. Venus in the Mirror: Roman Matrons in the Guise of a Goddess. Visual Past, v. 2.1, p. 137-154, 2015.

RIDGWAy, Brunilde Sismondo. The Aphrodite of Arles. American Journal of Archaeology, v. 80.2, p. 147-154, 1976.

SANTA-CRUZ, Maria. A oitava face do poeta: o amor natural - erotismo tardio ou alquimia do amor? Scripta, Belo Horizonte, v. 6.12, p. 82-99, 2003.

VITELLOZZI, Paolo. La voce dell'uomo e la voce del cosmo: percezione della dimensione sonora nella magia ellenistico-romana. Medea, v. I.1, p. 2-21, 2015.

WERnER, Elke Anna. The Veil of Venus: a Metaphor of Seeing in Lucas Cranach the Elder. In: BRINKMANN, Bodo. Cranach. Great Britain: Royal Academy of Arts, 2007. p. 99-109. 
${ }^{1}$ Trabalho realizado no CLUNL, Faculdade de Ciências Sociais e Humanas (FCSH), Universidade Nova de Lisboa, Portugal, financiado pela Fundação para a Ciência e a Tecnologia, I.P., no âmbito da Norma Transitória - DL 57/2016/ср1453/Ст0036.

${ }^{2}$ OLIVEIRA, 2014, p. 28.

3 BARBOSA, 1987, p. 9.

${ }^{4}$ Amor é um "sentimento de afeto, de carinho, de desejo, de emoção ardente que queima e dói, mas esse facto não invalida que encontremos o amor pelo outro como ser humano, aquele por quem se sente compaixão [...]. Estamos, portanto, por um lado, a falar de um amor com uma dimensão de desejo do outro, do seu corpo, da sua correspondência e, por outro, de amor fraterno e solidário" (OLIVEIRA, 2014, p. 29).

${ }^{5}$ Lima, 2006, p. 96.

${ }^{6}$ SANTA-CRUZ, 2003, p. 83.

${ }^{7}$ Idem, ibidem, p. 83

${ }^{8}$ Idem, 1985, p. 28.

${ }^{9}$ Idem, 2012a, p. 48.

${ }^{10}$ Idem, 1985, p. 303.

${ }^{11}$ Idem, ibidem, p. 320.

${ }^{12}$ Idem, ibidem, p. 402.

${ }^{13}$ ANDRADE, 2013, p. 11.

${ }^{14}$ Idem, ibidem, p. 38.

${ }^{15}$ Idem, ibidem, 2013, p. 30.

${ }^{16}$ Idem, 1985, p. 632.

${ }^{17}$ Idem, 2012b, p. 9.

${ }^{18}$ Idem, 1985, p. 402.

${ }^{19}$ Idem, ibidem, 1985, p. 241.

${ }^{20}$ Idem, 2014, p. 15

${ }^{21}$ Idem, ibidem, 2014, p. 16

22 Idem, 1985, p. 585.

${ }^{23}$ Idem, ibidem, 1985, p. 167.

${ }^{24}$ Idem, ibidem, p. 583.

${ }^{25}$ Idem, ibidem, 1985, p. 934.

${ }^{26}$ Grimal, s.u. 'Vénus'.

${ }^{27}$ BUENO, 2009, p. 78.

${ }^{28}$ ANDRADE, 2013, p. 48.

${ }^{29}$ Idem, ibidem, p. 21.

${ }^{30}$ BARBAS, 2002, p. 10.

${ }^{31}$ Veja-se uma explicação dos epítetos de Sena neste trecho em BUENO, 2009, p. 89-90.

${ }^{32}$ CARLOS, 1999, p. 56.

${ }^{33}$ BUENO, 2009, p. 73.

34 “'[1] neopitagorico Nicomaco di Gerasa, [...] nel suo Manuale d'Armonia riportò in auge in epoca imperiale l'antica dottrina Pitagorica dell'armonia musicale delle sfere celesti. Pitagora, che nel vi secolo a.C. aveva scoperto l'ordine armonico della scala musicale, aveva elevato quell'ordine alle sfere celesti dalle quali secondo lui esso derivava. Come le sette note dell'Ottava, i sette pianeti si sarebbero mossi in progressione armonica generando una melodia che secondo la tradizione Pitagora avrebbe più volte udito. Per Nicomaco, che mette esplicitamente in relazione i suoni vocalici, i numeri, e i pianeti, le vocali sono il suono di questa melodia mistica: esse sono 'elementi sonori' (phoneēnta stoichēia), e ciascuna vocale esprime il suono primordiale espresso una determinata sfera celeste" (VITELlozZI, 2015, p. 18). Mais tarde, Boécio, na sua obra De Institutione Musica, que se revelou importantíssima para o estudo da música no Ocidente (CASTANHEIRA, 2009, p. 8-9), retoma esta teoria, afirmando que a harmonia que rege a música é a mesma que rege as leis do universo e é responsável pela órbita dos planetas (CASTANHEIRA, 2009, p. 17, 135-137). Vide também APEL, 2003, p. 382.

35 "Before the twelfth century and even during it, [... B-flat [...] was characterized by some music theorists as soft and fickle, negative qualities associated with the female sex. [...] Perhaps not surprisingly (though it comes about indirectly), the association of B-flat with the feminine goes back to antiquity, to the Goddess Venus herself. Boethius matched the planet Venus in 
the heavenly spheres to the note trite synemmenon, identified in the Western scale with the note b-flat" (BLACKBURN, 2016, p. 20).

${ }^{36}$ KROPP, 2010, p. 230, 235.

${ }^{37}$ Veja-se CURTIS, 2003, p. 3-9, sobre a descoberta desta estátua no séc. XIX nas ruínas da ilha grega de Milos e a sua descrição minuciosa.

${ }^{38}$ Veja-se WERNER, 2007.

${ }^{39}$ Veja-se KLEINER, 1973, p. 387 e RIDGWAY, 1976 sobre a descoberta desta escultura na cidade francesa de Arles no séc. XVII e uma descrição minuciosa da mesma.

40 Descoberta em Roma no séc. XVII. Veja-se, para uma descrição mais pormenorizada, GRUMMOND, 1996, s.u. 'Capitoline Venus' e PICKUP, 2015.

${ }^{41}$ NESSELRATH, 1987.

${ }^{42}$ HASKELL, 1981, p. 316-318.

${ }^{43}$ GRIMAL, 1992, s.u. 'Elêusis'.

${ }^{44}$ Idem, ibidem, s.u. 'Édipo'.

${ }^{45}$ Idem, ibidem, s.u. 'Dédalo'.

${ }^{46}$ Idem, ibidem, s.u. 'Dánae'.

${ }^{47}$ Idem, ibidem, s.u. 'Belerofonte', 'Estenebeia'.

${ }^{48}$ Idem, ibidem, s.u. 'Ônfale', 'Héracles - v'.

${ }^{49}$ Idem, ibidem, s.u. 'Mégara', 'Héracles - I'.

${ }^{50}$ Idem, ibidem, s.u. 'Meleagro'.

${ }^{51}$ Idem, ibidem, s.u. 'Héracles - IV.14'.

52 Idem, ibidem, s.u. 'Héracles - III', 'Laomedonte'.

${ }^{53}$ Idem, ibidem, s.u. 'Atena'.

${ }^{54}$ Idem, ibidem, s.u. 'Hermafrodito'.

${ }^{55}$ ANDRADE, 2013.

${ }^{56}$ Idem, ibidem, p. 34. 